\title{
Atividades de fala e não-fala em gagueira: estudo $\operatorname{preliminar}^{* * * * * *}$
}

\section{Speech and non-speech activities in stuttering: a preliminary study}

\author{
Claudia Regina Furquim de Andrade* \\ Fernanda Chiarion Sassi** \\ Fabiola Staróbole Juste*** \\ Maria Isis Marinho Meira****
}

*Fonoaudióloga. Professora Titular do Departamento de Fisioterapia, Fonoaudiologia e Terapia Ocupacional da Faculdade de Medicina da Universidade de São Paulo. Endereço para correspondência: R. Cipotânea, 51 - Campus Cidade Universitária - São Paulo - SP - CEP 05360-160 (clauan@usp.br).

**Fonoaudióloga. Doutora em Ciências pela Faculdade de Medicina da Universidade de São Paulo. Fonoaudióloga do Curso de Fonoaudiologia do Departamento de Fisioterapia, Fonoaudiologia e Terapia Ocupacional da Faculdade de Medicina da Universidade de São Paulo.

***Fonoaudióloga. Doutora em Semiótica e Lingüística Geral pela Universidade de São Paulo.

****Fonoaudióloga. Professora Titular da Pontifícia Universidade Católica de São Paulo.

*****Trabalho Realizado no Departamento de Fisioterapia, Fonoaudiologia e Terapia Ocupacional da Faculdade de Medicina da Universidade de São Paulo.

Carta sobre Pesquisa

Artigo Submetido a Avaliação por Pares

Conflito de Interesse: não

Recebido em 22.08.2007.

Revisado em 17.01.2008; 22.02.2008.

Aceito para Publicação em 22.02.2008.

\section{Abstract}

Background: stuttering. Aim: to compare muscle activation in fluent and stuttering individuals during speech and non-speech tasks. Method: six adults divided in two groups: G1 - three fluent individuals; G2 - three stuttering individuals. Muscle activity (surface electromyography) was captured by disposable electrodes fixed in four regions. Testing situations: muscle rest tension, speech reaction time, non-verbal activity, verbal activity. Results: There was no significant statistical difference between the groups for the rest tension; $\mathrm{G} 2$ present longer speech reaction times; $\mathrm{G} 2$ presented muscle activity during the non-verbal task similar to that observed during rest; Muscle activity of G1 and G2 during the verbal task demonstrated to be similar. Conclusion: these results suggests that for $\mathrm{G} 2$ there is a poor control of timing for the coordination of motor processes.

Key Words: Fluency; Stuttering; Speech; Electromyography.

\section{Resumo}

Tema: gagueira. Objetivo: comparar a ativação muscular em indivíduos fluentes e gagos durante tarefas de fala e não-fala. Método: seis adultos foram divididos em dois grupos: G1 - três indivíduos fluentes; G2 - três indivíduos com gagueira. A atividade muscular (eletromiografia de superfície) foi captada por eletrodos fixados em quatro regiões. Situações testadas: tensão muscular de repouso, tempo de reação da fala; atividade não verbal e atividade verbal. Resultados: não houve significância estatística entre os grupos para a tensão de repouso; G2 apresentou tempo de reação de fala mais longo; G2 apresentou atividade muscular durante a tarefa não verbal semelhante a observada durante o repouso; a atividade muscular de G1 e G2 durante a tarefa verbal foi similar. Conclusão: estes resultados sugerem que G2 apresenta um pobre controle temporal para a coordenação dos processos motores.

Palavras-Chave: Fluência; Gagueira; Fala; Eletromiografia. 


\section{Introduction}

According to Loucks and De Nil (1), developmental stuttering in adults involves a deficit in oral kinesis. Studies have demonstrated that stuttering adults present difficulties in the timing of speech movements, fact that is observed when investigating the reaction time of muscles in verbal and non-verbal activities. These individuals present longer reaction times when compared to fluent individuals (2-8).

The purpose of the present study was to verify muscle activation in fluent and stuttering individuals during speech and non-speech tasks. The hypotheses of the study were:

. H1 - muscle rest tension is higher in individuals who stutter;

. H2 - speech reaction time is longer in individuals who stutter;

. H3 - muscle activity during speech is higher in individuals who stutter;

. H4 - muscle activity during non-verbal activities is similar for stuttering and fluent individuals.

\section{Method}

\section{Participants}

This research received prior approval from the Research Ethics Committee of the Institution (CAPPesq - HCFMUSP 1021/03)

Participants of this study were six adults divided in two groups: G1 with three fluent individuals, mean age of 36:6 years; G2 with three stuttering individuals, mean age of 26:3 years. All individuals were males and presented no history of communication deficits, hearing loss, neurological and/or cognitive disorders. Individuals of G1 did not present stuttering according to the Stuttering Severity Instrument (SSI-3 - Riley, 1994). Prior to data gathering, all of the participants of G2 went through 12 sessions of a Fluency Promotion Program associated to surface electromyography (PFPF-EMGS - Sassi, 2003). After the conclusion of the therapy program, these participants presented moderate to severe stuttering.

\section{Material}

Electromyographic data was obtained using an equipment with analogical/digital conversion and a specific program for data gathering and processing (Windows - EMG System do Brasil) installed in a computer (Dell Dimension 2400).

Electrodes were disposable Medtrace Mini Ag/ $\mathrm{AgCl}$ (diameter of $10 \mathrm{~mm}$ ).

Prior to the data gathering, the equipment was adjusted to the following specifications:

. frequency sampling per channel of $1000 \mathrm{~Hz}$;

. resolution of the analogic/digital conversion board of 12 bits;

. high pass filter of $20 \mathrm{~Hz}$;

low pass filter of $500 \mathrm{~Hz}$;

. total gain of 1000 (50 of each EMG channel and 20

of the active electrodes).

Active electrodes were used for the SEMG recordings following the configuration below:

. pre-amplifiers with a gain of 20;

. differential amplifiers with bipolar entry;

.2 meters of flexible steel-plated cable.

Procedure

Muscle activity was captured by disposable electrodes fixed in the inferior perioral region (inferior orbicularis oris - ORB); suprahyoid muscles (middle portion of the digastric mucle - $\mathrm{SH}$ ); neck (middle portion of sternocleidomastoideus muscle - SCM); and trapezius (TR).

Testing situations consisted of:

. muscle rest tension - each participant was instructed to remain the more relaxed as possible for 1 minute. After that, five seconds of muscle activity was recorded;

- speech reaction time - each participant was instructed to repeat the phrase "Barco na água" (boat on water) (Sassi \& Andrade, 2004) as soon as they heard the sound sign - a high pitched bip indicating the chronometer start. Only fluent productions, without disruptions, were accepted. The start of muscle activity recording coincided with the start of the chronometer. Only fluent utterances were accepted;

- brain deprogramming - using the same methodology applied in studies with neuroimage, a non-verbal activity was introduced - visualizing the word "NADA" - NOTHING - with the purpose of deprogramming brain activity (basal activation) for speech. In this situation, participants were instructed to look at the word shown on a card and 
think about nothing. Muscle activity was recorded for 30 seconds;

. non-verbal activity (thinking about a situation involving speech) - each participant was instructed to think of a speaking situation that they considered to be difficult. They were also instructed not make any facial movements during this task, muscle activity was recorded for 30 seconds;

. verbal activity (spontaneous speech) - a card o the game "Diga lá" (Vicari e Santos, 2005) was randomly chosen and each participant was asked to produce a self-expressive speech based on the given verbal order (e.g. tell me how you change a car tire), muscle activity was recorded for 30 seconds. The presence of speech disruptions did not invalidate the obtained data.

Results analysis

A total of 168 electromyographic recordings were analyzed. The gathered data were quantified in mean root square (RMS) by the signal gathering and processing program and expressed in microvolts $(\mathrm{uV})$.

For the rest condition, the obtained values represent the mean (RMS) electromyographic activity obtained in five seconds. Speech reaction time was obtained using a digital chronometer that measured the time interval between the instruction given to start speech and the actual production of speech. Muscle activation during each repetition of the target phrase was also analyzed. An interval marker was used in order to select the information intervals which were representative of the beginning and end of the muscle contraction (on and off situation) and therefore corresponded to the repetitions of the target phrase. The obtained values represent the average (RMS) electromyographic activity observed during the utterance of the target phrase. Regarding the other testing situations (brain deprogramming, nonverbal and verbal activity), the obtained values represent the average (RMS) electromyographic activity observed in 30 seconds.

For a few of the participants it was not possible to differentiate with precision the on and off situations from that which would represent the rest condition when analyzing muscle activity during the reaction time task. In this case, the first two seconds of muscle activity were selected, discarding the time used to start speech. The obtained RMS value was considered the muscle activity used to produce speech.

\section{Results}

For the statistical analysis of the results ANOVA was used. The level of significance was determined at $10 \%$, as the number of observations was low below six - for a few of the comparisons. The statistical analysis indicates that:

. there was no significant statistical difference between the groups for the rest tension of the tested muscles: $\operatorname{SCM}(\mathrm{F}=0.07 ; \mathrm{p}=0.804) ; \mathrm{TR}(\mathrm{F}=0.00 ; \mathrm{p}$ $=0.977) ; \mathrm{ORB}(\mathrm{F}=0.39 ; \mathrm{p}=0.568) ; \mathrm{SH}(\mathrm{F}=4.30 ; \mathrm{p}=$ 0.107);

. overall, speech reaction time is different for both groups $(\mathrm{F}=18.85 ; \mathrm{p}=0.001 *)$, independent of the repetitions $(\mathrm{F}=0.38 ; \mathrm{p}=0.691)$. Stuttering individuals present longer speech reaction times; . stuttering and fluent individuals presented similar muscle activity during speech $(\mathrm{F}=0.05 ; \mathrm{p}=0.819)$. When analyzing each muscle activity separately, results indicate that stuttering individuals presented similar muscle activity to that observed in fluent individuals for the following muscles: SCM $(\mathrm{F}=2.03 ; \mathrm{p}=0.185) ; \mathrm{TR}(\mathrm{F}=1.55 ; \mathrm{p}=0.242) ; \mathrm{ORB}(\mathrm{F}$ $=0.07 ; \mathrm{p}=0.791)$. Regarding $\mathrm{SH}$ muscles, their activity during the speech reaction time task was significantly lower for the group of stuttering individuals $(\mathrm{F}=8.87 ; \mathrm{p}=0.014 *)$;

. for the group of stuttering individuals muscle activity during the non-verbal tasks was similar to that observed during rest for all of the tested muscle groups. For the group of fluent individuals, on the contrary, there was a significant statistical difference when comparing muscle activity during the non-verbal task and the rest condition $(\mathrm{F}=4.08$; $\left.\mathrm{p}=0.076^{*}\right)$ - non-verbal muscle activity demonstrated to be higher when compared to that observed when muscles were at rest.

\section{Conclusion}

H1 - not confirmed; H2 - confirmed; H3 - not confirmed; H4 - partially confirmed.

Contradicting findings of the literature (13-14), high muscle activity during the rest position was not found for the group of stuttering individuals. This can be explained by the fact that these individuals had already concluded PFPF-EMGS. This fluency promotion program involves learning to relax speech muscles prior to the production of speech, bringing muscle activity close to rest muscle tension, as suggested by the consulted literature - i.e. between 0 and $5 \mathrm{uV}$ (15). By learning this ability the individual who stutters is able to 
attenuate unwanted sensory/motor stimulus and therefore is able to produce a more fluent speech (16-17).

The longer speech reaction times presented by the stuttering individuals can indicate the impact of poor timing over the motor system (motor processing). This can be one of the possible explanations, according to several authors $(2 ; 11 ; 16-$ 20) for the occurrence of stuttering.

Regarding the muscle activity during the speech reaction time task, taking in consideration only the $\mathrm{SH}$ muscles (movements of the tongue), it is observed that the group of stuttering individuals presented a significantly lower muscle activity when compared to that presented by the group of fluent individuals. This lower muscle activity can indicate the effort made by stuttering individuals to maintain their speech fluent; i.e. compared to their fluent pairs, these individuals had to use almost half of the muscle tension to present a speech free of disruptions. According to Conture (21) and Craig
(22-23) changes required by treatments that promote fluency associated to the level of stuttering (deficit of the motor processes involved in speech) are related to relapse and unsatisfactory post-treatment results.

As for the non-verbal task, it is observed that the group of fluent individuals presented a significantly higher muscle activity for the ORB muscle when compared to the values obtained for the rest position. This result suggests that even when the processing of speech (articulation) is not finalized, the motor system seems to be alert for speech production. The same was not observed for the group of stuttering individuals. This lack of alert for speech production can result from the deficit in the synchronization between motor processes involved in the production of speech, which in turn causes the longer reaction times to begin verbal tasks besides favoring the occurrence of speech disruptions (5;24-26).

\section{References}

1. Loucks TM, De Nil LF. Oral kinesthetic deficit in adults who stutter: a target-accuracy study. Journal of Motor Behavior. 2006;38(3):238-46.

2. De Nil LF, Abbs JH. Kinaesthetic acuity of stutterers and non-stutterers for oral and non-oral movements. Brain. 1991;114:145-58.

3. Caruso AJ. Perspectives regarding the clinical utility of a speech motor perspective on childhood stuttering. International Stuttering Awareness Day (ISAD) [CD-ROM], Mankato; 2000.

4. De Nil LF, Kroll RM, Houle S. Functional neuroimaging of cerebellar activation during single word reading and verb generation in stuttering and non-stuttering adults. Neuroscience Letters. 2001;302:77-80.

5. Bosshardt HG, Ballmer W, De Nil LF. Effects of category and rhyme decisions on sentence production. Journal of Speech, Language and Hearing Research. 2002;45(5):84458 .

6. Max L, Yudman EM. Accuracy and variability of isochronous rhythmic timing across motor systems in stuttering versus nonstuttering individuals. Journal of Speech, Language and Hearing Research. 2003;46:146-63.

7. Zimmerman G. Articulatory dynamics of fluent utterences of stutterers and nonstutterers Journal of Speech and Hearing Research. 1980;23:95-107.

8. Andrade CRF de. Abordagem neurolingüística e motora da gagueira. In: Ferreira LP, Béfi-Lopes D, Limongi SCO (Orgs.). Tratado de Fonoaudiologia, São Paulo: Roca, 2004. p. 1001-16.
9. Riley GD. Stuttering severity instrument for children and adults. Austin: Pro-Ed; 1994.

10. Sassi FC. Eletromiografia de superfície e promoção da fluência: estudos sobre a efetividade do tratamento. São Paulo, 2003. 180p. Tese (Doutorado) - Faculdade de Medicina, Universidade de São Paulo.

11. Sassi FC, Andrade CRF de. Acoustic analyses of speech naturalness: a comparison between two therapeutic approaches. Pró-Fono. 2004;16(1):31-8.

12. Vicari MI, Santos MTM. Diga lá. Material didáticoterapêutico para desenvolver aspectos pragmáticos da comunicação. THOT cognição e linguagem, Barueri; 2005.

13. Freeman FJ, Ushijima T. Laryngeal muscle activity during stuttering. Journal of Speech and Hearing Research. 1978;21(3):538-62.

14. Sassi FC, Juste F. Repouso e tempo de reação para fala: comparação entre gagos e fluentes. Revista da Sociedade Brasileira de Fonoaudiologia - Suplemento Especial - XIII Congresso Brasileiro de Fonoaudiologia; 2005. [CD-ROM]

15. Craig AR, Cleary PJ. Reduction of stuttering by young male stutterers using EMG feedback. Biofeedback SelfRegulation. 1982;7(3):241-55.

16. McClean MD. Surface EMG recording of the perioral reflexes: preliminary observations on stutterers and nonstutterers. Journal of Speech and Hearing Research. $1987 ; 30(2): 283-7$.

17. McClean MD. Lip-muscle reflexes during speech movement preparation in stutterers. Journal of Fluency Disorders. 1996;21:49-60. 
18. Zimmerman G. Articulatory behaviors associated with stuttering: a cinefluorographic analysis. Journal of Speech and Hearing Research. 1980;23:108-21.

19. Kleinow J, Smith A. Influences of length and syntactic complexity on the speech motor stability of the fluent speech of adults who stutter. Journal of Speech, Language and Hearing Research. 2000;43:548-59.

20. Kent RD. Research on speech motor control and its disorders: a review and prospective. Journal of Communication Disorders. 2000;33:391-428.

21. Conture EG. Treatment efficacy: stuttering. Journal of Speech and Hearing Research. 1996;39:S18-S26.
22. Craig A. Treating stuttering in older children, adolescents and adults: a guide for clinicians, parents and those who stutter. Sydney: University of Technology; 1998.

23. Craig A. Relapse following treatment for stuttering: a critical review and correlative data. Journal of Fluency Disorders. 1998;23:1-30.

24. Reich A, Till J, Goldsmith H. Laryngeal and manual reaction times of stuttering and nonstuttering adults. Journal of Speech and Hearing Research. 1981;24:192-6.

25. Peters HF, Hulstijn W, Starkweather CW. Acoustic and physiological reaction times of stutterers and nonstutterers. Journal of Speech and Hearing Research. 1989;32(3):668-80.

26. Salmelin R, Schnitzler A, Schimitz F, Freund HJ. Single word in developmental stutterers and fluent speakers. Brain. 2000;123:1184-202. 